\title{
Mediation Ethics and Regulatory Framework
}

\section{Teresa Moore}

\begin{abstract}
This article aims to explore principles governing mediation both in Ireland and in other jurisdictions, as well as looking at legislation regulating mediation elsewhere. Ireland's impending legislation subsequent to the Mediation Bill, 2017, will be examined.
\end{abstract}

\section{Keywords}

Mediation, ethics, framework, voluntariness, jurisdiction

\section{Introduction}

Mediation is a process in which a neutral third person assists persons involved in conflict to communicate effectively with each another in order to reach their own agreed decisions. The fundamental principles of mediation include confidentiality, self-determination, voluntariness and impartiality. This paper will examine the regulatory treatment of voluntariness and impartiality and briefly touch on selfdetermination. Various pieces of legislation will also be examined, including our own pending legislation here in Ireland, subsequent to the 2017 Mediation Bill and the effect such legislation will have on the above named principles. The Mediator Institute of Ireland (hereafter MII) Code of Ethics and Practice will also be looked at in respect of these principles.

\section{Voluntariness}

Head 6(1) of the Mediation Bill, 2017, refers to the voluntary nature of mediation by stating that "parties may engage in mediation..." and Head 6(2) explicitly states that "participation in mediation shall be voluntary at all times". Head 16(1) then goes on to state that "a court may... where it considers it appropriate... (a) invite the parties... to consider mediation" and (b) states that a court may "provide the parties... with information about the benefits of mediation...". Head 17(iv) goes on to state "if no mediation settlement has been reached, a statement as to whether, in the mediator's opinion, the parties engaged fully in the mediation" should be submitted to the court (where the parties have chosen to reenter the court proceedings). Whilst "invite" in Head 16(1) does seem to indicate and endorse the voluntary aspect of engaging in mediation, Head 17 gives a slightly different take in that it possibly suggests that the court may favour parties who have not wholeheartedly engaged in the mediation process. This could be problematic in the sense of voluntarily entering into and remaining in the process; 
the decision of whether or not to remain and any pending outcome should belong to the parties; this embodies both voluntariness and self-determination. Yet, in the opinion of the author, it seems the parties may be frowned upon by the court if they are perceived to have not engaged fully in mediation and such is supported by the mediator's statement submitted to the court. This could indeed have repercussions for the parties in truly being allowed to exercise self-determination as well as having a bearing on the element to which the participants fully believe in the neutrality of the mediator when the mediator is being asked to submit such a statement to the court.

A recent case referred to in an Irish Times article saw Judge Hughes giving the relevant parties an ultimatum: mediation or prison (Irish Times, 2016). In this case a mediator was assigned to tackle a 'sectarian' Islamic dispute in Longford. Here Judge Hughes warned the defendants that he would have no hesitation in handing out prison sentences if animosities continued. Judge Hughes then proceeded to adjourn the case pending the appointment of a mediator. Did Judge Hughes actually compel these parties to engage in mediation? It is the opinion of this author that he did indeed do so. However, what is important to emphasise at this point is the extent of such compelling. Hanks (2012, p.930) pointed out a key distinction with regard to voluntariness into and within the process. That is a crucial distinction to bear in mind.

Allen (2011, p.2) also points to the fact that entry into mediation does not compel the parties to settle: they can leave voluntarily without adverse consequences and revert to their litigated case at any time. This is where the true meaning of "voluntariness" arises and is important (Allen, 2011, p.2). But is Head 17(iv) supporting the true meaning of voluntariness? The MII Code of Ethics and Practice (Mediation Institute of Ireland, nos. 61, 62) also refers to voluntary participation and outlines also that any party, including the mediator, may leave the process at any time without having to give reasons.

While we saw Judge Hughes compelling the parties to engage in mediation, he will have no input in the process or the outcome; voluntariness will return to and remain with the parties once engaged in the process. One must ask does this strike a fair balance or is any impingement on voluntariness a step toward stripping away the fundamental nature of the principle? There are however very strong arguments in other jurisdictions, in Italy, for example, (examined below) where mandatory mediation in the sense of compelling parties to engage in it, has worked.

I think a danger lies where an obligation or discretion in some cases, as seen with the judiciary above, could ultimately open the door for some type of mandatory mediation and this could impinge upon one of the fundamental principles of mediation i.e. voluntariness. Heads 14 and 15 of the 2017 Bill also place an obligation on solicitors and barristers to provide information and advice on mediation. A written statement must then be submitted to the court when making an application to commence civil proceedings stating that mediation has been considered; where such a statement is not included, the court may adjourn proceedings until such a statement is provided. 


\section{An Analysis of the Voluntary Nature of Mediation in two Other Jurisdictions}

\section{England}

Hanks (2012, p.933) first draws attention to Directive 2008/52/EC; this directive applies to cross-border civil and commercial disputes. The Directive specifically states that 'nothing should prevent Member States from applying such provisions also to internal mediation processes' thus leaving it open for States to extend the provisions to local disputes. Hanks (2012, p.934) points to the fact that the terms of the Directive leave it open for States to implement mandatory mediation schemes (See Article 3 of Directive). The proposed Irish legislation in the form of the 2012 Bill does not go as far as prescribing for mandatory mediation although the recent Irish case referred to above would suggest that the judiciary could well exercise any discretion afforded to them to the maximum and beyond! The European Court of Justice has held that mandatory out-of-court proceedings are not contrary to European law, namely Article 6 of the ECHR (Hanks 2012: see footnote 38). It seems the view taken is that any such mandatory schemes are consistent with Article 6 so long as parties have eventual recourse to the courts (ibid., p.935). Article 6 of The European Convention on Human Rights zoning in on the right to a fair trial states that the ECJ has found that mandatory out-of-court proceedings are not contrary to European law so long as they do not result in a binding decision, do not cause a substantial delay in litigating, do not oust the court's jurisdiction due to limitation periods and are not excessively costly; Ireland's 2012 Bill takes such into consideration also.

The right of access to civil justice, as referred to in Article 6(1), has had specific relevance in England where the courts have taken the contrary view of article 6, that they are unable to compel nonconsenting parties to mediate (Halsey v Milton Keynes General NHS Trust [2004]). But while the English courts might not compel parties to enter into mediation, they do seem to punish parties for not doing so via adverse costs consequences in that a party may not get the costs award they might have expected because they refused to mediate. (Halsey v Milton Keynes General NHS Trust [2004]; Rolf v De Guerin [2011]; Gill v RSPCA [2009]). In the Halsey case, the Court of Appeal contradicted itself in some way as it held that it did not have the power to compel parties to mediate against their will as this would constitute a breach of Article 6 ECHR, but nevertheless the English courts go on to financially punish those parties who have refused to engage in mediation, as illustrated in the cases referenced above. The Civil Procedure Rules (CPR) which came into effect in 1999 place a strong emphasis on pre-action procedures; rule 44.3(5) thereof allows a court to make such adverse cost orders against a party who has refused to engage in pre-action protocols (Hanks, 2012, p.940); note that this is similar to Ireland's Legal Services Regulation Act, 2015, section 169(1)(g). Prince (2009) pointed to the introduction of a central telephone mediation helpline by the government resulting in what she describes as a loss of ownership by the court who had previously referred cases to their local mediation scheme (Hanks, 2012, p.940 citing Prince, 2009, pp.327-333). She notes that "In the future, the benefits of mediation can only be further appreciated if public awareness is raised; mediation is integrated into the legal system; and furthermore, the complex and challenging issues which are raised in order to do this are fully addressed" (Hanks, 2012,pp.940-941). 
Italy

Italy seems to have embraced mandatory mediation as a means of improving access to civil justice (Hanks, 2012, p.936). A delay of access of several years has had adverse consequences for the Italian government which, by 2000, had paid out over 600 million euro to individuals who brought claims that Italy had violated Article 6 of the ECHR (ibid.) Italy implemented Decree No. 5 on Corporate Mediation (2003) which introduced a system for the registration and accreditation of mediation organisations. If no agreement is reached the law gives mediators the power, if both parties so require, to recommend a solution at the end of the session which the parties must either accept or decline, with reasons (Hanks, 2012, p.937).

In 2009, Italy passed legislation empowering the government to issue statutory instruments on mediation extending the provisions of the 2003 Decree to other areas, allowing courts to award costs against a winning party that has refused a recommendation which is the same as the judgement (Hanks, 2012). The 2009 Decree also placed a duty on lawyers to inform clients in writing about the availability of mediation (Hanks, 2012). This is comparable with Heads 14 and 15 of Ireland's Mediation Bill, 2017.

Hanks (2012, pp.937-938) observes that a further Decree, No. 28 (2010) went far beyond the terms of the Directive. The scheme introduced a categorical mandatory mediation regime for disputes in real property, insurance, banking and financial agreements, division of assets, inheritance, family law, tenancy law, neighbour disputes, gratuitous loans for use, compensation claims for car or boat accidents, medical negligence claims and defamation in the press and other media. Hanks (2012, p.938) notes that there was fierce opposition to this from lawyers fearing that it would jeopardise their practices. It is evident that support of both legal practitioners and the judiciary, as outlined above, is paramount in the successful implementation of legislation governing mediation; this will be particularly important from an Irish perspective, given that our legislation is still pending. Interestingly the ECJ found no violations against Italy in relation to Article 6 ECHR from 2007 to 2011, providing a promising initial impression of the Italian mandatory mediation regime (Hanks, 2012, p. 939). Although not all European States have taken such drastic measures in response to the Directive, Hanks (ibid.) suggests that it is likely that we will see growing support for mandatory mediation in the European context.

\section{Impartiality/Neutrality}

Head 6(9) of Ireland's 2017 Bill states that it is for the parties involved in mediation to determine the outcome of the process; while this section specifically relates to the principle of self-determination, it ties in with impartiality/neutrality; crucial to the parties determining the outcome is the mediator remaining impartial to the parties and neutral to the process. Moore (2003) views impartiality as referring "to the absence of bias or preference in favour of one or more negotiators, their interests, or the specific solutions that they are advocating" (p.53). He refers to neutrality as referring "to the relationship or behaviours between intervenor and disputants" (ibid.). The MII Code is on par with this view, stating that the mediator must not take sides (Code of Ethics and Practice no. 56). It is also suggested by the MII 
code that if the mediator feels that impartiality cannot be maintained, the mediation process should be terminated (Mediation Institute of Ireland, no. 56). Bradley (2016, p.1) submits that while on paper, the fundamental principle of neutrality is a sound one, in that as a voluntary process the very success of mediation depends on all the parties feeling comfortable that the mediator is there to facilitate the process in a fair impartial way, in practice, she says that the pursuit of neutrality throws up a whole raft of issues.

Imagine a mediator so neutral that they give no support to either party (Bradley 2016, p.1). Is this what participants embroiled in conflict want? Mayer (2004, p.17) suggests not; they want assistance, advocacy, advice, power, resources, connections or wisdom. Whilst a mediator will announce that they intend to act in an impartial manner, it will undoubtedly be very hard to maintain this stance. Bradley (2016, p.1) suggests the reason for this is that as humans, mediators cannot completely detach from any views or feelings pertaining to the dispute or parties. A neutral mediator has been described by Fisher as 'a eunuch from Mars, totally powerless' (Hung, 2002, p.1, endnote). Hung asks what if there are circumstances where the mediator needs to be 'biased' in order to be neutral and impartial in a higher level of ethical consideration. Should he, she or it remain a Martian eunuch and uphold a superficially neutral and impartial position, or should he, she or it act according to conscience? Hung (ibid.) asks what about the client's self-determination? Should the mediator intervene or remain neutral and impartial if the agreement appears to be unfair or unethical to one of the parties? Head 6 (3)(a) of the 2012 Bill zones in on the right to self-determination, making it clear that it is for the parties themselves to determine the outcome of the dispute Nos. The MII's Code of Ethics zones in on self-determination as a fundamental principle of mediation making it clear that the content and the outcome of mediation belongs to the parties (Mediation Institute of Ireland, nos. 59-61).

Cloke (2001) holds that "there is no such thing as genuine neutrality when it comes to conflict; everyone has had conflict experiences that have shifted his or her perceptions, attitudes, and expectations, and it is precisely these expectations that give us the ability to empathise with the experiences of others" (p.12). Real fairness, Cloke submits, comes from using the past to gain an open, honest, humble perspective on the present (ibid.). Steier (1991) advocates self-reflexivity which is the 'turning back of one's experiences upon oneself and being conscious of ourselves as we see ourselves' (pp.2-5). Selfreflexivity recognises that our practices are culturally specific, not neutral, and requires the mediator to be 'explicit about the operation of power' (Ribbens, 1989, p.162) and to be mindful of their powerful position in the mediation process (Bagshaw, 2015, p.7). The reflexive mediator assumes a non-hierarchical position and works collaboratively with clients in a more collegial, partnership role (ibid.).

Bagshaw (ibid.) submits that dominant Western models of mediation presuppose that there is a roughly equal balance of power between the parties, and the mediator will work to balance any slight difference, but as outlined by Focault there are dominant voices and those which are subordinated and silenced in many instances (2015, p.9). For mediation outcomes to be fair and just, any issue of a use and abuse of power must be addressed (Bagshaw, 2015, p.9). Bagshaw further submits that it is impossible for mediators to be value-free, maintaining that the human rights of oppressed individuals and groups in a society can be easily ignored by mediators in the guise of neutrality (ibid., p.13). Whilst Bagshaw's article 
zones in on cultural biases and the marginalisation and subordination of women and indigenous peoples, the points he makes are relevant in the context of balancing power in all types of mediation settings.

Mediators in Ireland do not necessarily need to panic! While Head 8(2)(b) of the 2017 Bill does state that a mediator shall act with impartiality, Head 7 also allows for a facilitative process to become an evaluative process. A facilitative process dictates a mediator does exactly what it says on the tin, i.e. facilitate a process for resolving disputes; assisting parties who are in conflict to have open conversation culminating in a jointly reached solution. There are two other types of approach which a mediator can assume: evaluative mediation and transformative mediation. The former approach addresses the weaknesses in each party's case and focuses on legal rights as opposed to interests; a mediator can have direct influence on an outcome here. The transformative approach focuses on empowering parties from a perspective of weakness to one of strength. Interestingly in the CEDR's 2016 Mediation Audit (CEDR, 2016) when asked "facilitative or evaluative?" - most mediators said they veered between the two and “...when the going gets tough" they definitely veered toward the latter approach (Bradley, 2016, pp.1-2). Bradley suggests that when adopting an evaluative approach, a mediator will need to drop hints about their line of thinking (ibid. p.1). In fact, she submits that the reality testing, challenging and coaching which are required to reach settlement almost always require the mediator to take and express a view or feeling in a way which supports one or more parties. Striking a balance here is an enormous skill for a mediator to acquire. Bradley submits that the parties must perceive a necessary degree of fairness (ibid., p.2).

Paramount for any mediator is to outline at the beginning of a process that the mediator may meet with or telephone the parties separately, so that they are both aware of the possibility of separate interaction. The MII's Code of Ethics and Practice no.57 states that nothing shall prevent the mediator from talking to, phoning, communicating with or meeting one Party separately, with or without the knowledge of the other Party, provided it has been explained to the Parties that this might happen and that impartiality and neutrality are maintained. "Balanced" mediation will require a responsibility to protect both parties. (Bailey, 2014, p.1 citing Benjamin, 1998). If mediators are too tightly bound by procedural requirements for a scrupulously neutral process they will lose the ability to fashion a process that truly addresses the needs of clients (Taylor, 1997, p.222). Equally, if mediators start muscling clients into positions they do not wish to take or prevent them from making agreements they freely chose, it may no longer be a neutral process at all (ibid.). The enormous skill of striking a balance, referred to above, is again something that Taylor points to in outlining that the skill lies in knowing when and how to intervene without compromising the entire process; such a skill is the "hallmark of a reflective and competent practitioner" (ibid.). Crucial to the principles of voluntariness, impartiality and selfdetermination is that both sides have the right to opt out of any outcome they perceive as being unfair. 


\section{Conclusion}

Any impending legislation will need both legal practitioners and the judiciary on side and a strong awareness of the benefits of mediation. However, a danger lies where an obligation or discretion in some cases, as seen with the judiciary above, could ultimately open the door to some type of mandatory mediation and this could impinge upon one of the fundamental principles of mediation i.e. voluntariness. It is important to bear in mind the distinction between voluntariness into and within the process, as referred to at the outset. While all MII mediators are governed by the MII's Code of Ethics and Practice any law will supersede that - clearly when the 2017 Bill becomes law all MII mediators will be bound by this first and foremost. 


\section{References}

Allen, T. (2011) "Dunnett v Railtrack really lives: sanctioning for refusing to mediate", CEDR Article Bagshaw, D. (2015) "Mediation in the World Today: Opportunities and Challenges" Journal of Mediation and Applied Conflict Analysis 2(1) accessed at https://www.maynoothuniversity.ie/edward-m-kennedyinstitute/journal- mediation-and-applied-conflict-analysis Bailey, P. (2014) "Neutrality in Mediation: An Ambiguous Ethical Value", Journal of Mediation and Applied Conflict Analysis, 1 (1)

Benjamin, R. (1998) “The Risks of Neutrality - Reconsidering the Terms and Concept” available from http://www.mediate.com/articles/benjamin.cfm Bradley, K. (2016) "Neutrality - core principle or principle hurdle”, CEDR Article 27 July 2016 Cloke, K. (2011) Mediating Dangerously - The Frontiers of Conflict Resolution. San Francisco: Jossey-Bass Hanks, M. (2012) “Perspectives on Mandatory Mediation”, UNSW Law Joumal, Volume 35(3) p.929-952. Irish Times (2016) "Mediator assigned to tackle 'sectarian' Islamic dispute in Longford" http://www.irishtimes.com/news/crime-and-law/courts/district-court/mediator-assigned-to-tacklesectarian-islamic-dispute-in-longford-1.2810625

Hung, Hin (2002) "Neutrality and Impartiality in Mediation" ADR Bulletin, 5 (3) Mayer B., (2014) Beyond Neutrality: Confronting the Crisis in Conflict Resolution

San Francisco: Jossey-Bass

Mediation Bill, 2012 available at www.justice.ie

Mediation Institution of Ireland, www.themii.ie Code of Ethics, Nos. 59-63

Moore, C. (2003) The Mediation Process - practical strategies for resolving conflict

$3^{\text {rd }}$ ed., San Francisco: Jossey-Bass

Prince, S. (2009) "ADR after the CPR: Have ADR initiatives now assured mediation as an integral role in the civil justice system in England and wales?" in Dwyer, D. (ed.) The Civil procedure Rules Ten Years on. Oxford University Press Ribbens ,J. (1989) “Interviewing: an 'unnatural situation'?”, Women's Studies International Forum, 12 (6)

Taylor, A. (1997) "Concepts of Neutrality in Family Mediation: Contexts, Ethics, Influence, and Transformative Process”, Conflict Resolution Quarterly, 14 (3) Spring: 215-236. 


\section{Cases cited}

Halsey v Milton Keynes General NHS Trust [2004] 4 ALL ER 920 Gill v RSPCA [2009] EWHC B34 Civ Rolf v De Guerin [2011] EWCA Civ 78

\section{Legislation/Proposed Legislation cited}

Civil Procedure Rules, (CPR) 1999 (UK)

Decree No.5 on Corporate Mediation 2003 (Italy) available at http://eur- lex.europa.eu Decree 2009 (Italy) available at http:/ / eur-lex.europa.eu Decree No.28 (2010) available at http:// eurlex.europa.eu Directive 2008/52/EC Article 3

European Convention on Human Rights, (ECHR) Article 6 Legal Services Regulation Act, 2015

Mediation Bill, 2012

\section{Biography}

Teresa Moore resides in Cork, Ireland. She was awarded an LLB in Irish Law in November 2016 having studied Law at Griffith College Cork. Teresa presented a paper on 'Israel: a modern day apartheid?' at the Inaugural Postgraduate and Early Career Conference at Griffith College Dublin in June 2016; this paper was also published by the Irish Law Times.

Teresa went on to complete a post-grad certificate in Mediation at Griffith College Cork during which time she began her research into the regulatory framework surrounding mediation; such forms the basis for this article. At present Teresa works part-time in the area of social policy and an advocacy related field. 